Article

\title{
Loofah Sponges as Bio-Carriers in a Pilot-Scale Integrated Fixed-Film Activated Sludge System for Municipal Wastewater Treatment
}

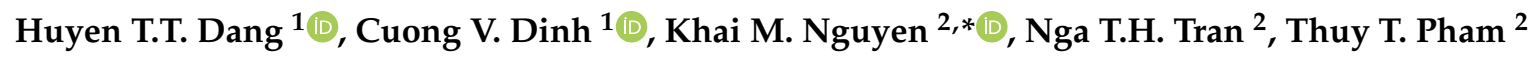 \\ and Roberto M. Narbaitz ${ }^{3}$ \\ 1 Faculty of Environmental Engineering, National University of Civil Engineering, No 55, Giai Phong Street, \\ Hanoi 84024, Vietnam; huyendtt@nuce.edu.vn (H.T.T.D.); cuongdv@nuce.edu.vn (C.V.D.) \\ 2 Faculty of Environmental Sciences, VNU University of Science, 334 Nguyen Trai, Thanh Xuan, \\ Hanoi 84024, Vietnam; tranthihuyennga@hus.edu.vn (N.T.H.T.); phamthithuy@hus.edu.vn (T.T.P.) \\ 3 Department of Civil Engineering, University of Ottawa, 161 Louis Pasteur Pvt., \\ Ottawa, ON K1N 6N5, Canada; narbaitz@uottawa.ca \\ * Correspondence: khainm@hus.edu.vn
}

Received: 15 May 2020; Accepted: 5 June 2020; Published: 10 June 2020

\begin{abstract}
Fixed-film biofilm reactors are considered one of the most effective wastewater treatment processes, however, the cost of their plastic bio-carriers makes them less attractive for application in developing countries. This study evaluated loofah sponges, an eco-friendly renewable agricultural product, as bio-carriers in a pilot-scale integrated fixed-film activated sludge (IFAS) system for the treatment of municipal wastewater. Tests showed that pristine loofah sponges disintegrated within two weeks resulting in a decrease in the treatment efficiencies. Accordingly, loofah sponges were modified by coating them with $\mathrm{CaCO}_{3}$ and polymer. IFAS pilot tests using the modified loofah sponges achieved $83 \%$ organic removal and $71 \%$ total nitrogen removal and met Vietnam's wastewater effluent discharge standards. The system achieved considerably high levels of nitrification and it was not limited by the loading rate or dissolved oxygen levels. Cell concentrations in the carriers were twenty to forty times higher than those within the aeration tank. Through 16S-rRNA sequencing, the major micro-organism types identified were Kluyvera cryocrescens, Exiguobacterium indicum, Bacillus tropicus, Aeromonas hydrophila, Enterobacter cloacae, and Pseudomonas turukhanskensis. This study demonstrated that although modified loofah sponges are effective renewable bio-carriers for municipal wastewater treatment, longer-term testing is recommended.
\end{abstract}

Keywords: integrated fixed-film activated sludge systems; modified loofah sponge; bio-carrier; microbial density; municipal wastewater

\section{Introduction}

One of the greatest challenges for developing countries is wastewater treatment. Rapid urbanization led to a more concentrated release of wastewaters into the environment, which has significantly impacted humans and wildlife. Organic compounds and nutrients from municipal or industrial wastewater contaminate ecosystems, e.g., rivers, ponds, or even groundwater [1]. Low-cost wastewater treatment utilizing local materials can contribute to addressing this challenge, especially in developing countries. Wastewater stabilization ponds or constructed wetlands are known as appropriate low-cost wastewater treatment technologies, but they have large land area requirements, and the treatment efficiency is rather difficult to control. In developing countries, the conventional activated sludge process (CAS) has been the standard treatment method. During the last decades, new fixed-film processes, such as moving bed biofilm reactors (MBBR) and integrated fixed-film 
activated sludge (IFAS) systems, have also been widely applied [2,3]. These processes have performed well in terms of organics and nitrogen removal in both municipal $[4,5]$ and industrial wastewater treatment applications [6]. The key differences between MBBR and IFAS are the possible longer hydraulic retention time and recycle of sludge in the IFAS system [7].

IFAS is a biological wastewater treatment process, which combines suspended growth and attached growth processes by adding free-floating biofilm carriers into the aeration tank $[2,8]$. Biofilm carriers, which have a lower density than water, are kept in suspension, moving throughout the tank volume by the aeration. The relatively large surface of the carriers serves as physical support and protection for attached microbiological growth and leads to large bacterial populations throughout the reactor. A key advantage of IFAS over CAS is that the biomass attached to the bio-carriers is retained within the system. This leads to higher solids retention times and biomass concentrations, thus reducing the required reactor volume/footprint [9]. Conversion of CAS systems to IFAS systems is relatively inexpensive and it will yield higher system capacities or improved removal efficiencies [7]. IFAS also produces better settling solids, so the secondary clarifier can operate at higher solid loadings and produce lower concentration effluents [9]. The attached biomass also results in more stable nitrification [7].

The most common biofilm carriers used in IFAS and MBBR systems are polyethylene bio-carries [10] and polyurethane sponges [11]. However, the cost of plastic bio-carriers makes them less attractive for applications in developing countries. In addition, plastic carriers are environmentally unfriendly materials as they may generate secondary waste, i.e., plastic waste. The application of natural materials as carriers for MBBRs or IFASs has attracted significant attention [12]. Examples of alternative materials tested as bio-carriers include black volcanic ashes [13], natural zeolites [14], fungal pellets [15], diatomaceous earth [16], and Moringa oleifera seeds [17].

Loofah is an annual herbaceous plant from the cucurbitaceous family, and its fully developed fruit is the source of the loofah scrubbing sponges normally used in bathrooms and kitchens. They are also used for other applications such as for reinforcing composite materials [18]. Loofah sponges are lightweight, highly porous and have a large surface area, which makes them suitable as a bio-carrier material in IFAS and MBBR systems. So far, the most common research interest for loofah sponges is their adsorption capability, e.g., adsorption of phenol [19], heavy metal [20], and organic compound [21]. Loofah sponges are composed of hemicellulose (22\%), $\alpha$-cellulose $(60 \%)$, lignin (10.6\%), and others $(7.4 \%)$ [19]. These components are biodegradable in water [22,23]. In order to enhance the durability of loofah sponges in aqueous solutions, some studies have modified them. Hideno et al. [24] modified the loofah sponges by immersing them in an acetic anhydride solution to create acetylated sponges for the immobilization of cellulase-producing microorganisms. On the other hand, they soaked the luffa sponges in a $\mathrm{Ca}(\mathrm{OH})_{2}$ solution to increase the durability of the sponges to up to 10 days in a lab-scale bioreactor [25]. It should be noted that the modification with the alkaline solution was reported to reduce the leaching of hemicelluloses, waxes, impurities, and lignin from the fibers [26].

The objective of this study is to modify loofah sponges and use them as bio-carriers in a pilot-scale IFAS unit for the treatment of municipal wastewater. The experiments evaluated the organic compound and nitrogen removals, as well as the bacterial density and bacterial community composition. This study is novel in that it presents the first pilot-scale IFAS wastewater treatment study using loofah sponges as bio-carriers. This treatment approach increases the sustainability of IFAS by using a low-cost renewable material as bio-carriers.

\section{Materials and Methods}

\subsection{Preparation and Modification of Loofah Sponges}

Loofah sponges were collected and cut into pieces (about 5-6 cm long). The sponges were rinsed with distilled water (DI) and oven-dried at $105^{\circ} \mathrm{C}$ for $24 \mathrm{~h}$. The objective of the loofah sponge modification was to increase their durability. To strengthen and increase the fiber hardness and service 
life, Liu et al. (2016) coated their loofah sponges with $\mathrm{CaCO}_{3}$ layer by soaking them in a lime solution. The $\mathrm{CaCO}_{3}$ coating was formed based on the following equation:

$$
\mathrm{Ca}(\mathrm{OH})_{2}+\mathrm{CO}_{2} \rightarrow \mathrm{CaCO}_{3} \downarrow+\mathrm{H}_{2} \mathrm{O}
$$

In this study, the modification process was carried out as follows. First, pieces of loofah sponges were soaked in $500 \mathrm{~mL}$ of a $30 \% \mathrm{Ca}(\mathrm{OH})_{2}$ solution (ACS reagent $\geq 95.0 \%$, Sigma-Aldrich) for $48 \mathrm{~h}$, followed by drying at room temperature for $24 \mathrm{~h}$. Second, the samples were then immersed in $200 \mathrm{~mL}$ of $30 \%$ by volume commercial Acrylic - Styrene polymer solution (Bondex, India) for $1 \mathrm{~h}$. The polymer solution had a viscosity of $3-8\left(\mathrm{~kg} \mathrm{~m}^{-1} \mathrm{~s}^{-1}\right)$, at $30^{\circ} \mathrm{C}$ and $\mathrm{pH}=8-10$, and is alkali resistant. The polymer coating was intended to increase the loofah fiber's water tolerance and possibly increase its surface area. The polymer solution was received as an emulsion which was converted into a suspension (via dispersion) by mixing it with a small amount of water. The main benefits of polymer coating were its plasticization and the possibility of greater microorganism adhesion. Third, the samples were removed from the polymer solution, allowed to drain and dry at room temperature for $24 \mathrm{~h}$, and then stored for the experiments. The pristine and modified loofah samples were characterized before conducting the tests.

To assess the impact of different coating strategies and the durability of these modified sponges in water, a set of wastewater contact experiments were conducted using five types of loofah sponge samples, including a pristine loofah sponge (Sample 1), a $\mathrm{CaCO}_{3}$-coated loofah sponge (Sample 2), a loofah sponge sample coated by immersion in both a $\mathrm{Ca}(\mathrm{OH})_{2}$ solution and a $30 \%$ polymer solution (Sample 3), a loofah sponge sample coated by spraying with the polymer solution (Sample 4), and a loofah sponge sample coated by immersing it in 30\% polymer solution only (Sample 5). This test was implemented prior to conducting the IFAS experiment to evaluate the organic and nitrogen removal efficiencies.

\subsection{IFAS Pilot-Scale Experiment}

The pilot-scale IFAS system was set up at Kim Lien wastewater treatment plant (WWTP) in downtown Hanoi (Figure 1). This system was designed for the simultaneous removal of organic compounds and nitrogen compounds. The system consists of an anoxic compartment, a larger aerobic IFAS bioreactor compartment, and a sedimentation compartment. The feed wastewater was the Kim Lien wastewater treatment plant's primary effluent. It was pumped to the anoxic compartment (Figure 1), where a mixer (2) was employed to ensure that the solids did not settle. The wastewater then passed to the aerobic compartment which contained the loofah sponges, which were moving within the tank due to the aeration. From there, the wastewater flowed into the sedimentation chamber. The sedimentation chamber effluent was stored in a separate water tank. As in Figure 1, the blower (1) was used to supply air for the bioreactor. In addition, wastewater was recycled from the aerobic compartment to the anoxic compartment by a pump (3) and sludge was recycled from the sedimentation compartment to the anoxic compartment by a pump (4) to enhance the nitrogen removal by denitrification. The tank dimensions and operational parameters are presented in Table 1 . The pilot system flowrate was $1 \mathrm{~m}^{3} \mathrm{~d}^{-1}$. Note that the hydraulic retention time (HRT) of the aeration/bioreactor compartment was within the 3 to $7 \mathrm{~h}$ conventional range [7]. The anoxic zone's HRT was purposely chosen to be slightly longer than normal (1-2 h), this was to ensure denitrification is not hindered. The pristine and modified loofah sponges were put into the MBBR tank at a bulk volume filling ratio of $30 \%$. 


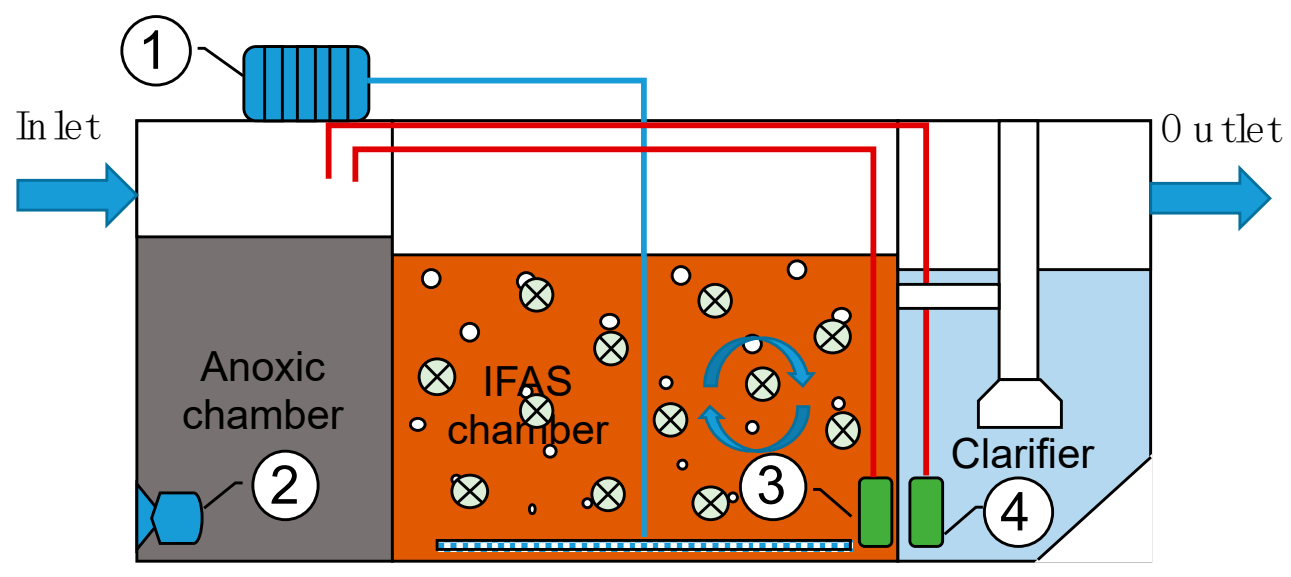

$1-\mathrm{A}$ ir com pressor

$2-\mathrm{M}$ ixer

3-R ecycle pum p from IFA $S$ to anoxic cham ber 4-R ecycle pum p from clarifier to anoxic cham ber

Figure 1. Experimental setup of the integrated fixed-film activated sludge (IFAS) system.

Table 1. Pilot-scale moving bed biofilm reactors (MBBR) specifications and operational conditions.

\begin{tabular}{lll}
\hline Treatment Compartment & Parameters & Value \\
\hline Anoxic compartment & Wet dimensions, $L \times W \times H(\mathrm{~m})$ & $0.4 \times 0.4 \times 0.7$ \\
& Water volume $\left(\mathrm{m}^{3}\right)$ & 0.112 \\
& Hydraulic retention time $(\mathrm{h})$ & 2.65 \\
\hline Aerobic compartment (MBBR) & Wet dimensions $L \times W \times H(\mathrm{~m})$ & $0.4 \times 0.8 \times 0.7$ \\
& Hydraulic retention time $(\mathrm{h})$ & 5.3 \\
& Water volume $\left(\mathrm{m}^{3}\right)$ & 0.224 \\
& Circulation rate, $R$ & $0.5 Q$ \\
& Carrier filling rate & $30 \% \mathrm{~V}$ \\
& Air supply $\left(\mathrm{m}^{3}\right.$ min $\left.^{-3}\right)$ & 0.1 \\
\hline Sedimentation compartment & Wet dimensions, $L \times W \times H(\mathrm{~m})$ & $0.4 \times 0.4 \times 0.7$ \\
& Sludge circulation rate, $R_{\mathrm{b}}$ & $0.5 Q$ \\
\hline
\end{tabular}

During the initial experiments with pristine loofah sponges, the feed wastewater had a $\mathrm{pH}$ of $7.4 \pm 0.25$, a temperature of $25 \pm 4.5^{\circ} \mathrm{C}$, a chemical oxygen demand (COD) concentration of $175.2 \pm 32.5 \mathrm{mg} \mathrm{L}^{-1}$, and total nitrogen (TN) concentration of $45.7 \pm 1.9 \mathrm{mg} \mathrm{L}^{-1}$. The ammonia and COD concentrations fluctuated due to dilution with the occasional rainfall events, as the Kim Lien WWTP is served by a combined sewer system. In the aerobic compartment, the air was provided at a rate of $0.1 \mathrm{~m}^{3} \mathrm{~min}^{-1}$ to ensure the attached biomass had sufficient dissolved oxygen and the bio-carriers materials remained suspended during the reaction process. Because of logistic limitations, the duration of the experiments was three months. The IFAS run with the unmodified loofah fibers carriers was conducted first, and it was followed by the IFAS run using the modified loofah fiber carriers. The pilot-scale system was initially seeded with activated sludge which was taken from the secondary settling tank of the Kim Lien WWTP. During the tests, samples were collected from the inlet, the MBBR compartment and the sedimentation compartment, and then analyzed for COD, $\mathrm{TN}, \mathrm{N}-\mathrm{NH}_{4}$, dissolved oxygen (DO), $\mathrm{pH}$ and temperature. The samples were collected and analyzed daily for $\mathrm{pH}$, temperature, and dissolved oxygen (DO), and twice per week for the other parameters (TN, N-NH 4 , COD). 


\subsection{Analytical Method}

The analysis of the above water quality parameters was performed according to the procedures in "standard methods for the examination of water and wastewater" [27].

The structure of loofah was evaluated by an optical microscope (Carl Zeiss, Germany). The surface area was analyzed by the Brunauer-Emmett-Teller (BET) method using a Gemini VII 2390 V1.02T analyzer (Micromeritics Instrument Corp., Norcross, GA, USA).

The bio-carrier specific volumetric filling ratio $\left(V_{\mathrm{FR}}\right)$ was determined by filling an empty 1-L beaker with loofah sponges, adding water to the 1-L mark, then removing the sponges and measuring the volume of water $\left(V_{2}\right)$. Due to the occupancy of carriers, the volume of water remained in the beaker $\left(V_{2}\right)$ shall be less $1 \mathrm{~L}$. $V_{\mathrm{FR}}$ is defined by the following equation:

$$
V_{\mathrm{FR}}=\frac{V_{2}}{V_{1}} \times 100 \%
$$

where $V_{1}$ is the volume of water in a $1 \mathrm{~L}$ beaker $\left(V_{1}=1 \mathrm{~L}\right)$, and $V_{2}$ is the volume of water remained in a $1 \mathrm{~L}$ beaker after removing the loofah sponges $(\mathrm{L})$.

The density of loofah sponges was calculated using the following equation:

$$
\rho=\frac{m}{V}
$$

where $m(\mathrm{~g})$ and $V\left(\mathrm{~cm}^{3}\right)$ are the mass and volume of the loofah sponge.

The microbial population and density were determined by colony culture and counting methods. The microorganisms in loofah samples were cultured in Luria-Bertani (LB) medium including peptone $\left(15 \mathrm{~g} \mathrm{~L}^{-1}\right)$, agar $\left(15 \mathrm{~g} \mathrm{~L}^{-1}\right)$, yeast $\left(5 \mathrm{~g} \mathrm{~L}^{-1}\right)$ and $\mathrm{NaCl}\left(5 \mathrm{~g} \mathrm{~L}^{-1}\right)$. After two days, the colonies were counted to estimate the density as Colony Forming Units (CFUs) (Vietnam standard method TCVN 9716:2013, or ISO 8199:2005). In addition, 16S-rRNA analysis was performed three times during the testing, to determine the phylogenetic information of the isolated microorganism. The procedure is described in detail elsewhere [28,29]. Microbial analysis was performed for the following samples: mixed liquor from the aeration tank of the Kim Lien WWTP (as a reference); the solution in the pilot-scale aeration compartment; and the bio carriers within the IFAS pilot system.

The Spearman correlation coefficients were calculated for pairwise comparisons of organic loading rate and COD removal, and the evaluation of the correlation between ammonium loading rate and its reduction during the nitrification process. This was performed using XLSTAT 2019.3.1 (Addinsoft, USA).

\section{Results and Discussion}

\subsection{Characterization of Loofah Sponges before and after Modification}

Figure $2 \mathrm{a}, \mathrm{b}$ show images of the pristine and modified loofah sponge bio-carriers. It can be seen that the sponges have a porous and fibrous structure, which can provide a favorable environment for the attached bacterial growth. Additionally, the modified loofah sponge pieces are covered by a white layer. This layer was created by the $\mathrm{CaCO}_{3}$ precipitate and polymer modifications of the loofah fibers (Figure 2b). Figure 2c,d presented the optical microscope images of two carrier types. Notably, after the $\mathrm{CaCO}_{3}$ precipitate and polymer modifications, a thin layer is observed on the fiber structure (Figure 2d). The precipitate and film layer could represent a film that prevents water from penetrating into the loofah fibers and, thus, enhances the durability of the loofah fiber bio-carriers. The images also show that the $\mathrm{CaCO}_{3}$ and polymer layer did not fill the sponge's voids, the modified sponges maintained the original mesh-like structure. 


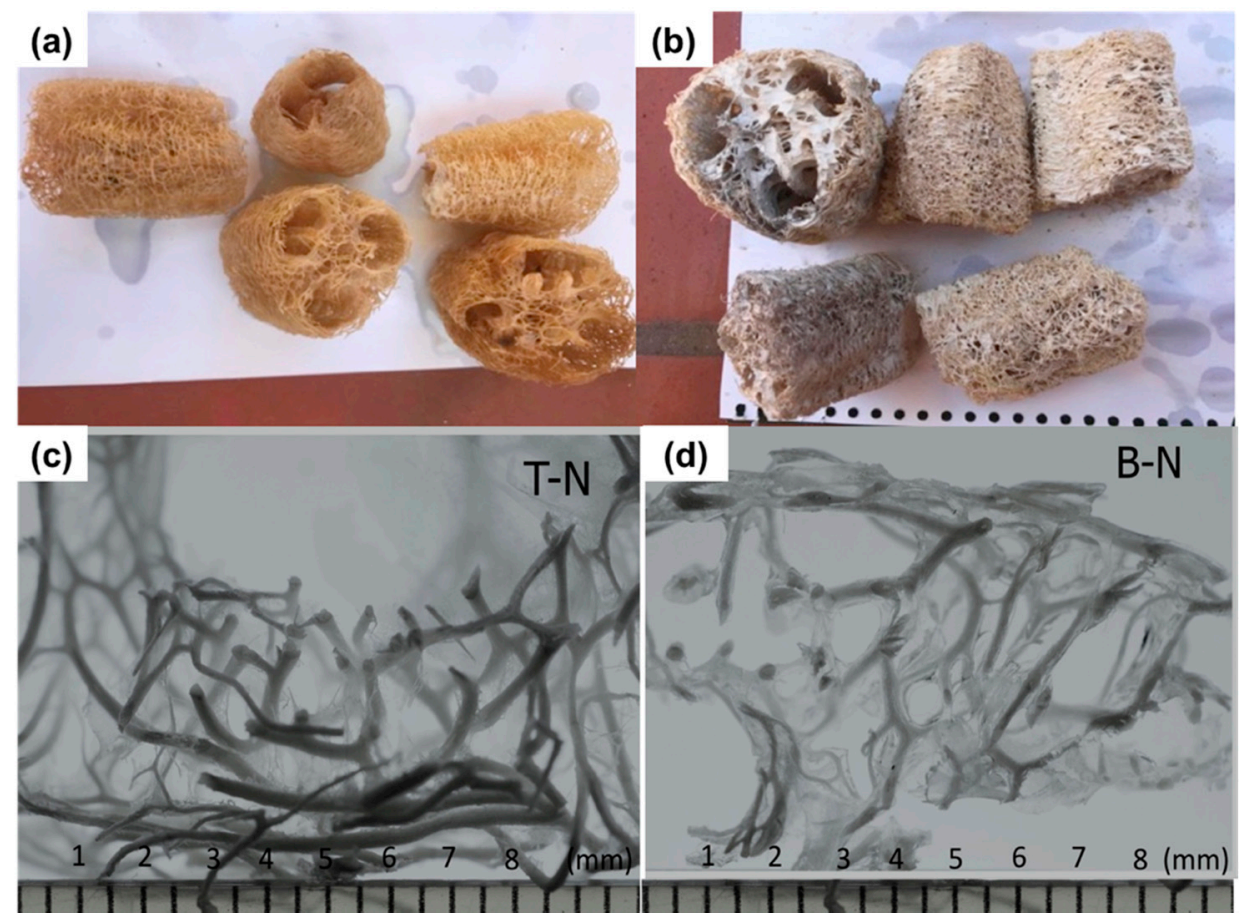

Figure 2. (a,b) Real images and (c,d) microscope images ( $\times 10$ magnification) of the pristine and modified loofah sponges, respectively.

Table 2 shows the key characteristics of pristine and modified loofah sponges. As shown, the densities of the pristine loofah sponge $\left(0.25 \mathrm{~g} \mathrm{~cm}^{-3}\right)$ and the modified loofah sponge $\left(0.26 \mathrm{~g} \mathrm{~cm}^{-3}\right)$ samples were significantly less than $1 \mathrm{~g} \mathrm{~cm}^{-3}$, indicating that the loofah fiber carriers will float in water, and be suitable as bio-carriers. The slight increase in the density of the modified loofah sponge is likely due to the formation of the $\mathrm{CaCO}_{3}$ precipitate and polymer layer on the material surface. The average carriers' filling ratios were relatively similar, that were $87.5 \%$ and $82.5 \%$ for the pristine and modified samples, respectively. This confirms that the $\mathrm{CaCO}_{3}$-polymer modification did not significantly alter the porous structure of the loofah sponges. Moreover, the value of the BET specific surface area of the modified loofah sponge samples was $0.875 \mathrm{~m}^{2} \mathrm{~g}^{-1}$, which was higher than that of the pristine loofah samples of $0.018 \mathrm{~m}^{2} \mathrm{~g}^{-1}$. The higher surface area is attributed to the successful $\mathrm{CaCO}_{3} /$ polymer-composite coating of the loofah sponge surface, in which the higher surface area is attributed primarily to micropores in the coating layer. As discussed by Yuan et al. [30], a larger specific surface area would normally result in higher biomass attachment. Overall, the chemical modification of loofah sponges coated the framework structure and accordingly should increase the durability.

Table 2. Characteristics of the pristine and modified loofah sponges.

\begin{tabular}{ccc}
\hline Parameters & Pristine Samples & Modified Samples \\
\hline Material Size $(\mathrm{mm})$ & $30-50$ & $30-50$ \\
Density $\left(\mathrm{g} \mathrm{cm}^{-3}\right)$ & 0.25 & 0.26 \\
Specific Carrier Filling ratio $(\%)$ & $87.5 \% \pm 3 \%$ & $82.5 \% \pm 3 \%$ \\
BET surface area $\left(\mathrm{m}^{2} \mathrm{~g}^{-1}\right)$ & 0.018 & 0.875 \\
\hline
\end{tabular}

\subsection{Evaluation of Durability of Loofah Sponges in Water}

The durability test of the materials was performed by soaking the pristine loofah sponge and several differently modified loofah samples into the active bioreactor tank (Figure 3a). This is a realistic approach, as the loofah sponge carriers were exposed to the real operating environment of a municipal wastewater treatment plant. It was found that after 5 days due to decomposition, only a portion of 
the pristine loofah sponge (sample 1) remained (Figure 3b). The samples coated by a layer of $\mathrm{CaCO}_{3}$ or polymer (samples 2, 4, and 5) degraded within three weeks. These results are consistent with the findings of Do et al. [25], whose loofah sponges coated with $\mathrm{CaCO}_{3}$ only lasted up to 10 days in the lab-scale MBBR tank. Only sample 3, coated by both $\mathrm{CaCO}_{3}$ and polymer, remained intact after 30 days of operation (Figure 3c). Thus, the protective film of $\mathrm{CaCO}_{3}$ precipitate and polymer successfully prevented the destruction of the loofah sponge during the contact with the wastewater and microorganisms. The combination of $\mathrm{CaCO}_{3}$ and polymer coating increased the loofah sponge's water durability beyond that provided by $\mathrm{CaCO}_{3}$ coating alone. These modified sponges, coated with both $\mathrm{CaCO}_{3}$ and polymer, were selected for a long-term test in the IFAS system to evaluate the organic and nutrient removal.
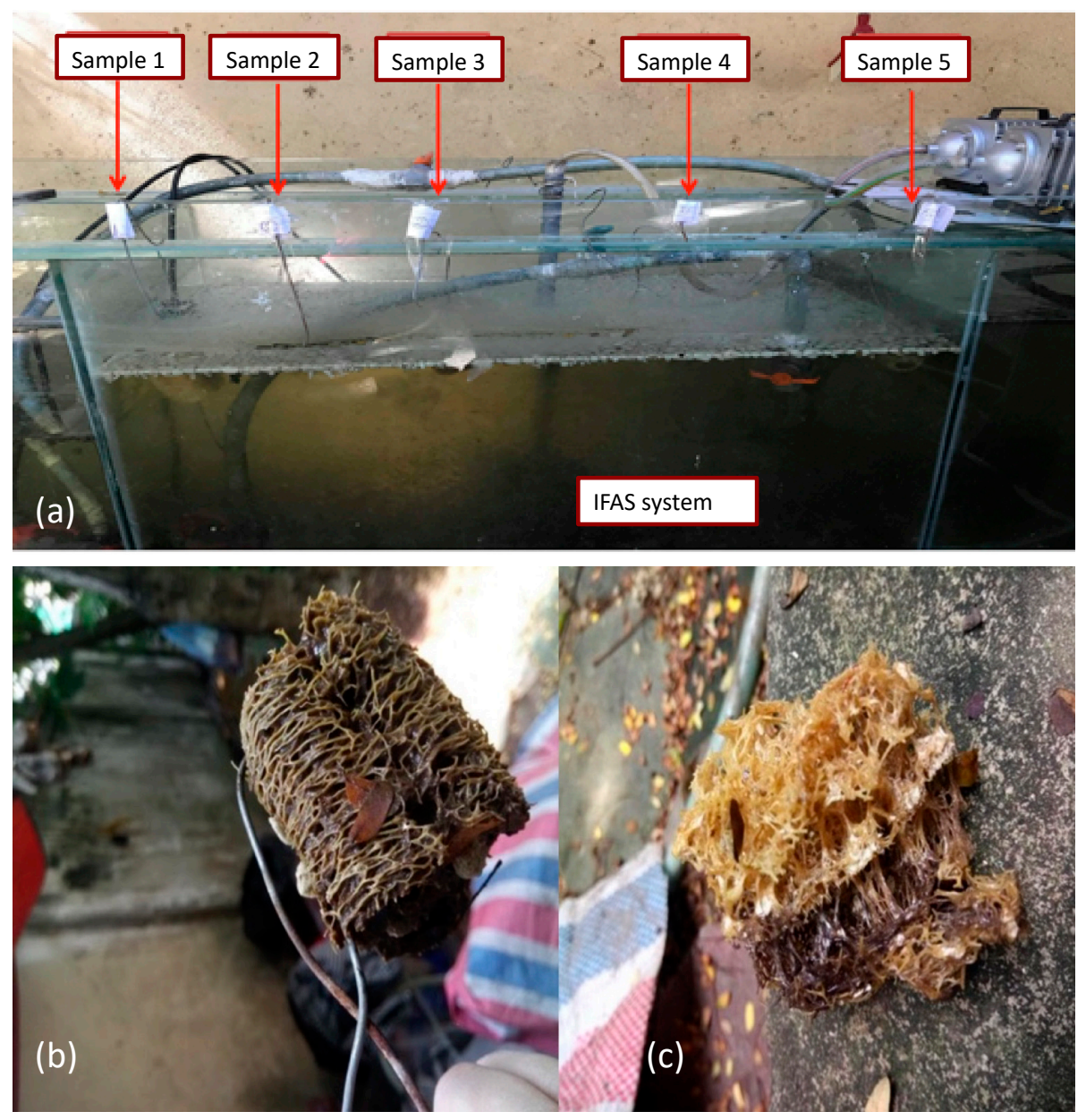

Figure 3. Evaluation of durability of loofah sponges in IFAS tank (a) the arrangement of 5 samples; (b) the sample 1 after 5 days; (c) the sample 3 after 30 days.

\subsection{IFAS Removal of Organic Compounds}

The COD removal of the IFAS system using the pristine loofah sponges as bio-carriers is presented in Figure 4a. The COD of the influent wastewater was $175.2 \pm 32.5 \mathrm{mg} \mathrm{L}^{-1}$ (Figure $4 \mathrm{a}$ ), so this was a relatively low organic strength municipal wastewater. The COD of the effluent was $35.2 \pm 18.9 \mathrm{mg} \mathrm{L}^{-1}$, which is lower than Vietnam's COD standard for treated wastewater of $75 \mathrm{mg} \mathrm{L}^{-1}$ [31] (Figure 4a). The IFAS/pristine loofah carriers' system initially achieved a high average COD removal $(79 \% \pm 13 \%)$. However, the COD removal decreased to $62 \%$ after 15 days. It is speculated that this was caused by the structural degradation of the loofah sponges, which decreased the mass of attached microorganisms that were retained within the bioreactor. 

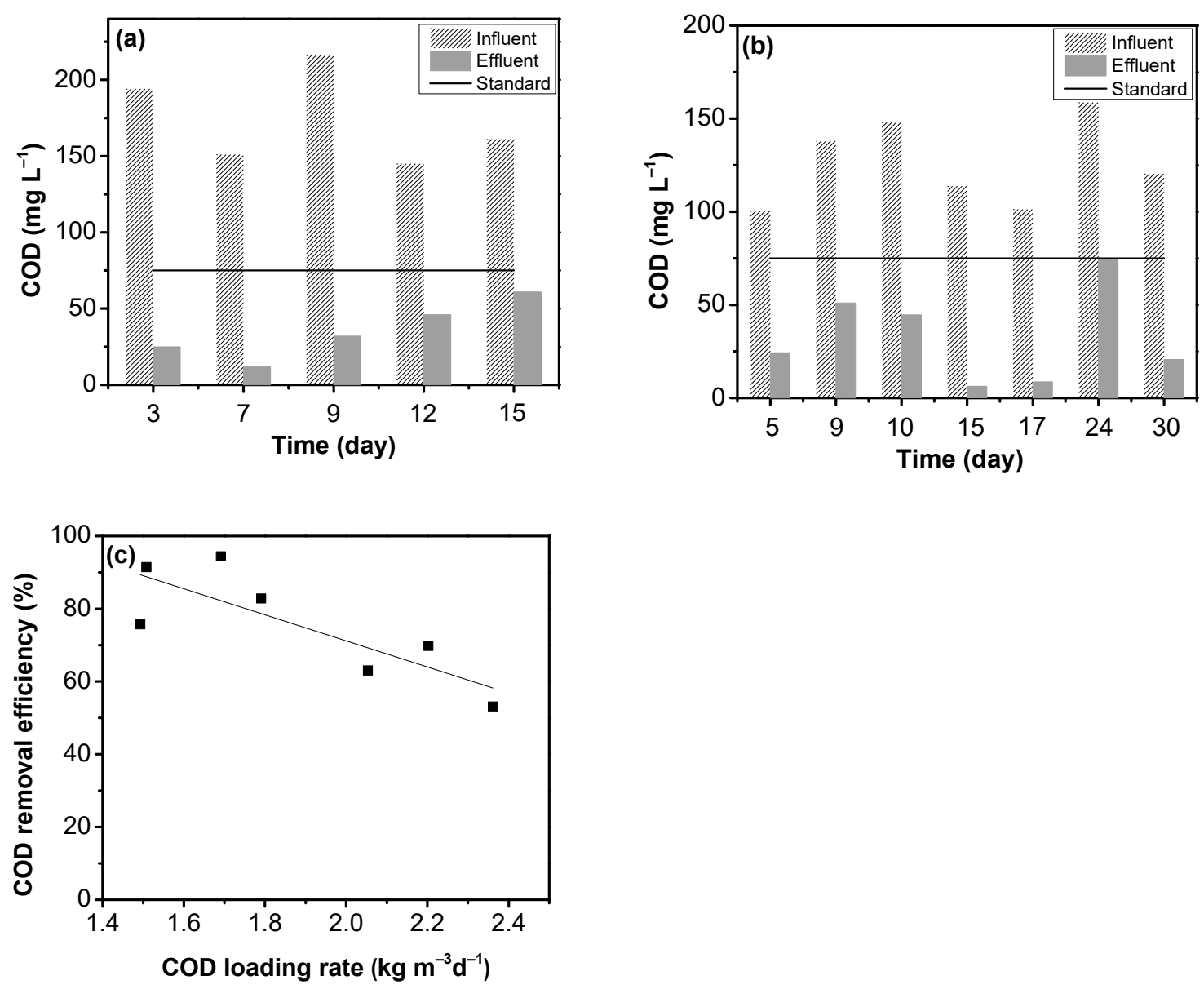

Figure 4. COD removal of the (a) pristine and (b) modified loofah sponges and (c) correlation of COD removal and COD loading rate in the IFAS/modified loofah sponges' system.

Figure $4 \mathrm{~b}$ presents the IFAS/modified loofah sponge system's influent and effluent COD concentrations for the 30-day run. It should be noted that by the second week, the COD removals exceeded $90 \%$, however, on the 24th day, there was a significant drop in the COD removal. This was attributed to the degradation of some modified loofah sponge bio-carriers, so some new modified loofah sponges were added to replace the degraded ones, and this improved the COD removals (Figure $4 \mathrm{~b}$ ). And by the 30th day, the system achieved $82.8 \%$ COD removal. Given that the feed wastewater was real municipal wastewater, the research group had no control over the feed concentrations and composition. The IFAS/modified loofah bio-carrier run had lower feed COD concentrations than the IFAS/pristine loofah bio-carrier run $\left(125.8 \pm 22.9 \mathrm{mg} \mathrm{L}^{-1}\right.$ versus $\left.175.2 \pm 32.5 \mathrm{mg} \mathrm{L}^{-1}\right)$. Thus, the former had lower COD loadings that likely explains the higher COD removals for this run. In addition, the organic compounds in the feed wastewater also included a non-biodegradable fraction, so the degradable COD removals were even higher than the percentages reported above.

Overall, the modified loofah sponge carriers can help the IFAS system remain effective for a longer time than the pristine loofah sponge carriers. In addition, the percent COD removals efficiency of the IFAS using loofah bio-carrier is comparable with commercial plastic carriers (40-95\%) [32,33].

Figure $4 \mathrm{c}$ presents the relationship between the COD fraction removed and the COD loading rate $\left(\mathrm{kg} \mathrm{COD} \mathrm{m}^{-3}\right.$ day $\left.^{-1}\right)$ in the IFAS/modified loofah sponge pilot. This loading rate is based on the volume occupied by the sponges, i.e., $30 \%$ of the total. Statistical analysis showed a negative correlation (the Spearman coefficient $=-0.71, p<0.05)$, and a linear fit of data also presented a negative correlation with $R^{2}=0.662$. This indicates that the COD removed fraction decreased with the increasing COD loading rate from 1.4 to $2.4 \mathrm{~kg} \mathrm{~m}^{-3} \mathrm{~d}^{-1}$. This is consistent with previous studies $[34,35]$. In fact, the COD 
removal performance may depend on a variety of factors such as the bacterial density, the bacteria types, and the operating conditions (i.e., $\mathrm{DO}, \mathrm{pH}$, and temperature) [33].

\subsection{Removal of Nitrogen Compounds}

The nitrogen removal performance of the IFAS/pristine and modified loofah sponge pilots are shown in Figure 5. For both runs, there was a significant fluctuation in the influent TN concentration. During the IFAS run with the pristine sponges, the influent TN concentrations were higher than during the IFAS- modified bio-carrier run $\left(45.7 \pm 1.9 \mathrm{mg} \mathrm{L}^{-1}\right.$ versus $\left.29.7 \pm 9.3 \mathrm{mg} \mathrm{L}^{-1}\right)$. As observed, after 9 days the IFAS/pristine loofah sponge system achieved a relatively high $\mathrm{TN}$ removal (i.e., $80.3 \%$ ) (see Figure 5a), however, the nitrogen removal gradually decreased after 15 days (i.e., $47.4 \%$ ). This is likely due to the degradation of the loofah fibers after 15 days, as discussed above. The influent and effluent TN concentrations for the IFAS/modified loofah sponge bio-carriers are presented in Figure $5 \mathrm{~b}$. In all the testing, the IFAS/modified loofah bio-carrier system's effluent met Vietnam's $20 \mathrm{mg} \mathrm{TN} \mathrm{L}^{-1}$ standard [31]. It should be noted that the TN removals also decreased on the 24th day of the run, however, the addition of new bio-carriers did not result in recovery as for the COD removals. This may be due to the fact that nitrifying bacteria grow more slowly than heterotrophs, and thus require more time to recover. The average percent TN removal using the modified carriers were superior to those observed for the pristine loofah bio-carriers, $71 \pm 8 \%$ versus $53 \pm 22 \%$. This may have been influenced by the lower feed TN concentrations during the IFAS/modified loofah bio-carrier run.
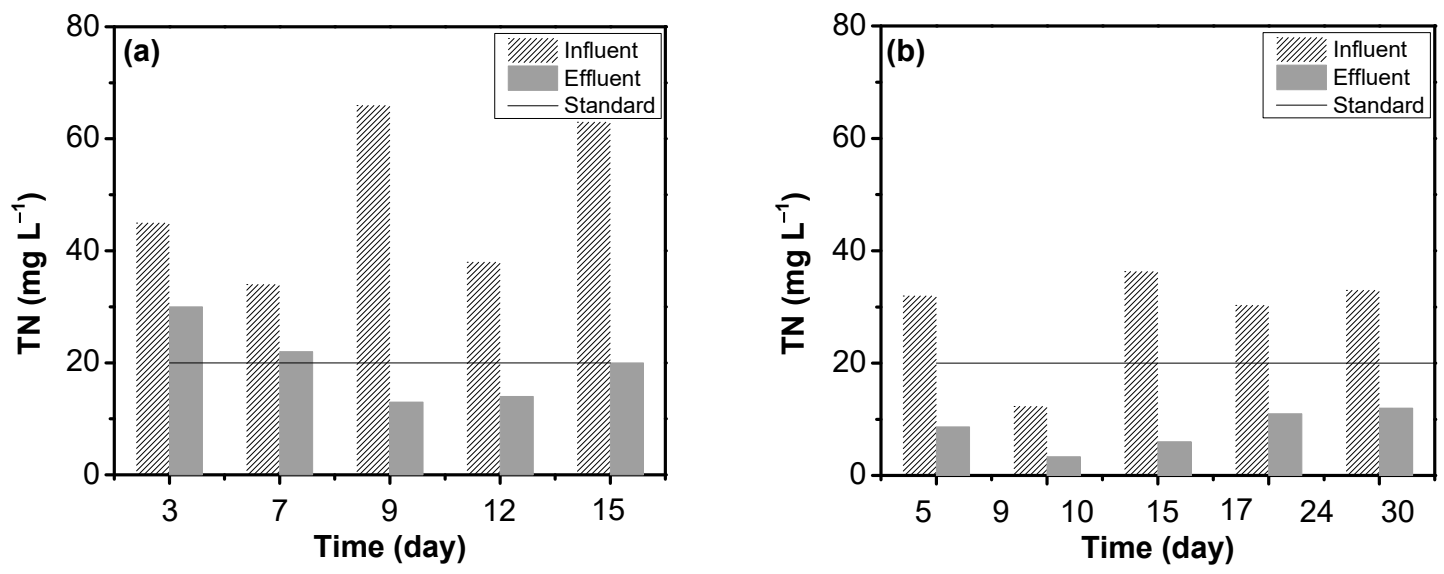

Figure 5. Nitrogen removal of the IFAS pilot using the (a) pristine and (b) modified loofah sponges.

The IFAS/modified loofah sponge run also investigated ammonia removals. TN is composed of ammonia, organic nitrogen, nitrite, and nitrate. The feed concentrations during this run also fluctuated, the TN concentration was $29.7 \pm 9.3 \mathrm{mg} \mathrm{N} \mathrm{L}^{-1}$ and the $\mathrm{NH}_{4}$ was $19.7 \pm 6.9 \mathrm{mg} \mathrm{N} \mathrm{L}^{-1}$. Given that raw wastewater generally have virtually no $\mathrm{NO}_{2}$ and $\mathrm{NO}_{3}$, the raw wastewater contained approximately $10 \mathrm{mg} \mathrm{L}^{-1}$ in the form of organic nitrogen. The relationship between nitrification rate and ammonium loading rate was investigated on the IFAS/modified loofah sponge run. (Figure 6a). The wide range in the ammonia loadings was due to the fairly wide range of ammonia feed concentrations. It was found that the data in Figure 6a fit a straight line rather well $\left(R^{2}=0.995\right)$. Further statistical analysis confirmed the positive correlation with the Spearman coefficient of $0.997, p<0.05$. The slope of this line represents the percent ammonia removal, and the constant slope shows that the IFAS/modified loofah bio-carrier system was very consistent. The percent $\mathrm{NH}_{4}-\mathrm{N}$ removal was $90.4 \pm 4.5 \%$, so nearly complete nitrification was achieved. This high level of nitrification is logical given the low organic loadings applied to the system, i.e., the nitrifying bacteria were not significantly impacted by competition with the heterotrophs that oxidize the COD. The straight-line results in Figure 6a also demonstrate that the ammonia loading rate does not limit ammonia removal. Figure $6 \mathrm{~b}$ shows the impact of DO on the fraction of $\mathrm{NH}_{4}-\mathrm{N}$ removed. It shows that DO levels in the range of $2-5 \mathrm{mg} \mathrm{L}^{-1}$ do not have a 
significant impact on the level of nitrification. Thus, it can be concluded that the IFAS system with $\mathrm{CaCO}_{3} /$ polymer modified loofah sponge bio-carriers can successfully treat the organic and ammonium of municipal wastewater. The loofah sponge modification was critical in improving the durability of the eco-friendly carriers. Longer-term testing is recommended to evaluate their long-term durability.
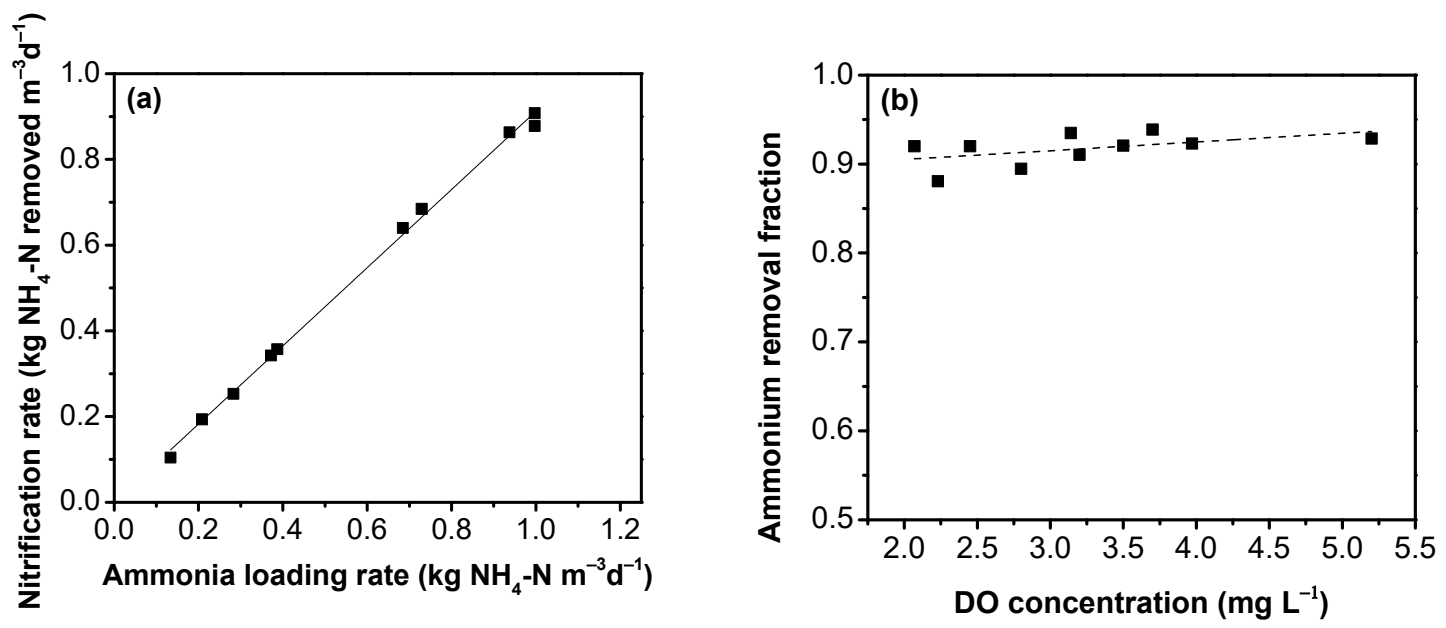

Figure 6. Nitrification analysis: (a) nitrification rate and ammonium loading rate and (b) DO and ammonium removal rate.

It is noteworthy that the IFAS/modified loofah bio-carrier system was capable of removing approximately $90 \%$ of the ammonia but only $71 \%$ of the TN. This may be because part of the TN is composed of organic nitrogen compounds, some of which may not be degradable [7]. Another possibility is that denitrification in the anoxic compartment was not fully effective due to difficulties in maintaining anoxic conditions, because of the large rate of mixed liquor recycle to the anoxic tank. At least on one occasion, the DO levels increased above $0.5 \mathrm{mg} / \mathrm{L}$.

\subsection{Microbial Evaluation}

The density of microorganisms and related types of microorganisms were evaluated during the second IFAS phase with the modified bio-carriers. In Table 3 , day " 0 " indicates the time when the microorganisms were fully adapted to the influent wastewater and grew well in the reactor. On that day, the microorganism density in the oxic tank of Kim Lien WWTP was $2.6 \times 10^{5} \mathrm{CFU} \mathrm{mL}^{-1}$, while it was $1.5 \times 10^{4} \mathrm{CFU} \mathrm{mL} \mathrm{m}^{-1}$ in the IFAS tank solution, and an even higher bacterial density in the bio-carriers $\left(6.7 \times 10^{5} \mathrm{CFU} \mathrm{gr}{ }^{-1}\right)$. On day " 0 ", the modified sponges had already been in the IFAS system for one week and their bacterial density was higher than the control modified loofah sponges $\left(5.33 \times 10^{5} \mathrm{CFU} \mathrm{gr}{ }^{-1}\right)$. So this was evidence that there was microorganism growth on the sponges once they were put in the system. As the system continued its operation, the density of microorganisms increased proportionally. This is logical because there was bio-growth within the tanks and on the fibers (carriers). Most of the time, the accumulation of microorganisms was higher in the IFAS tank than the oxic tank of the full-scale plant. This showed that the existence of bio-carriers helped increase the biological community and activity in the aerated reactor. In addition, the microbial growth was significant on bio-carriers (twenty to forty times higher in loofah sponges than in IFAS tank solution). The increasing biofilm formation can also be seen when comparing the color in active loofah sponges and the clean ones (Figures 2 and 3). On the 24th day, the bacterial mass on the carriers is much lower. The drop in bacterial mass on the carriers was much more significant than expected based on the visual observations of the modified loofah bio-carrier degradation. So presumably the sponges degraded to the point that they could not support as large a biofilm, or possibly the biofilm was using components of the sponge as substrate and they exhausted the supply of these components. 
Table 3. The density of microorganisms in the IFAS/modified loofah sponges' system.

\begin{tabular}{|c|c|c|c|c|}
\hline $\begin{array}{l}\text { Operational } \\
\text { Time } \\
\text { (Day) }\end{array}$ & $\begin{array}{l}\text { In Oxic Tank of } \\
\text { Kim Lien Wwtp } \\
\quad\left(C F U \mathrm{~mL}^{-1}\right)\end{array}$ & $\begin{array}{l}\text { In Ifas with Modified } \\
\text { Loofah Sponges } \\
\left(\mathrm{CFU} \mathrm{mL} \mathrm{mL}^{-1}\right)\end{array}$ & 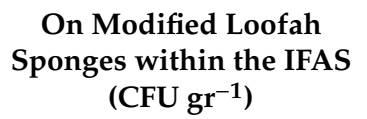 & 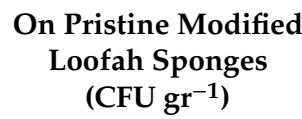 \\
\hline 0 & $2.6 \times 10^{5}$ & $1.6 \times 10^{4}$ & $6.7 \times 10^{5}$ & \\
\hline 2 & $5.2 \times 10^{5}$ & $5.0 \times 10^{4}$ & $16.9 \times 10^{5}$ & \\
\hline 6 & $6.7 \times 10^{5}$ & $25.5 \times 10^{4}$ & $187.0 \times 10^{5}$ & $5.33 \times 10^{5}$ \\
\hline 12 & $14.1 \times 10^{5}$ & $129.0 \times 10^{4}$ & $290.0 \times 10^{5}$ & \\
\hline 24 & $22.8 \times 10^{5}$ & $3.92 \times 10^{4}$ & $11.3 \times 10^{5}$ & \\
\hline
\end{tabular}

The treatment efficiency in terms of COD and TN removal also decreased at this time. It confirms the fact that microorganisms played a critical role in transforming organic and ammonia in the reactor. It should be noted that after the 24th day, some new modified loofah sponges were added to replace the degraded ones, so the COD and TN removals increased again (Figures 4 and 5). Based on these results, for better treatment efficiency one should regularly replace the modified loofah sponges as their working life span is approximately four weeks.

Understanding the dominant microorganisms in suspension and the bio-carriers would help optimize conditions for their growth and maximize pollutant removal. The microorganism strains developed in the tank system and on modified loofah sponges were collected on days " 12 " and " 24 " for the microbial analysis to determine the dominant microorganisms. Results from dendrograms were calculated with the un-weighted pair group method and combined with arithmetic mean algorithm (UPGMA) clustering (Pearson correlation coefficient) of 16S-rRNA patterns. They identified six main groups of microorganism strains: (1) Common strain: round colonies, thick, diameter between 1-2 mm, white, most abundant (below Figure 7a, labeled 5.3C1), (2) Branched strain: round colonies, branched at the edge, diameter between 3-4 mm, white (labeled 5.2MS2) (Figure 7a), (3) Red strain: round colonies, thick, red, more intense color in the center, diameter between 2-3 mm (labeled 5.2PR3) (Figure 7a), (4) Orange strain: round colonies, orange, diameter between 1-2 mm (labeled 5.2MS4), (5) Yellow strain: round colonies, yellow, diameter between 1-2 mm (labeled 5.1MR5) (Figure 7a) and (6) White strain: curve-round colonies, smooth surface, diameter 4-15mm $(4 \mathrm{C} 1,4 \mathrm{C} 2,4 \mathrm{C} 4)$ (Figure $7 \mathrm{~b}$ ).
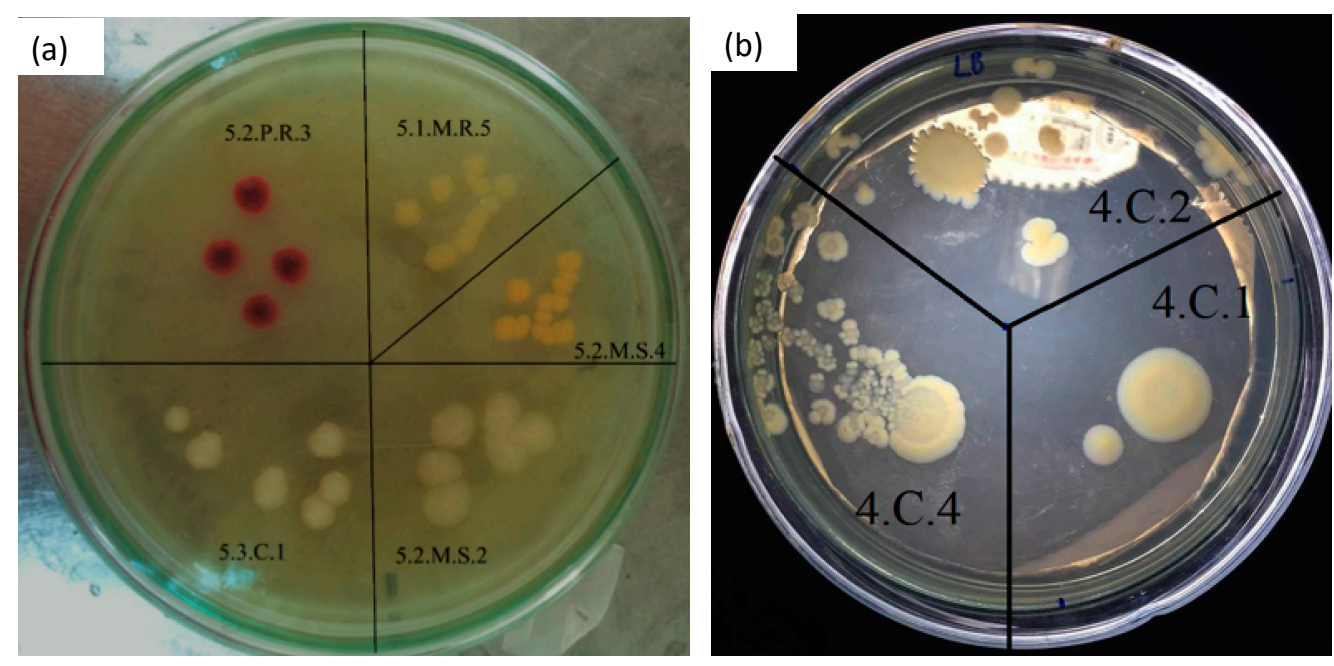

Figure 7. Clusters of isolated strains based on the 16S rRNA gene sequence analysis, with (a) Common strain (5.3C1), Branched strain (5.2MS2), Red strain (5.2PR3), Orange strain (5.2MS4), Yellow strain (5.1MR5), (b) White strain (4C1,4C2,4C4).

Based on the 16S rRNA gene sequence analysis of these samples, some major microorganism strains commonly found in wastewater were identified (Table 4). They include: 
(i) Kluyvera cryocrescens is Gram-negative, a member of Entertobacteriaceae, which has been found in sewage, milk wastewater, hospital wastewater [36]. Klebsiella aerogenes which is also in the Entertobacteriaceae family, is Gram-negative bacteria that is widely distributed in water, air, soil, can be isolated from sediment of polluted rivers [37].

(ii) Exiguobacterium indicum are Gram-positive facultative anaerobes, which have been retrieved from psychrophilic and thermophilic environments [38]. They can neutralize highly alkaline wastewater [39].

(iii) Bacillus tropicus is a Gram-positive bacillus, belonging to Firmicutes, Bacilli, Bacillales, Bacillaceae. They are aerobic microorganisms, best grown in aerobic conditions, in the optimal temperature of $15-32{ }^{\circ} \mathrm{C}$. They have been used in wastewater treatment systems due to their ability to clean up contaminated components with low oxygen content and decompose organic matter in high concentrations in a short time [40].

(iv) Aeromonas hydrophila is a Gram-negative bacterium, rod-shaped, belonging to Proteobacteria, Gammaproteobacteria, Aeromonadales, Aeromonadaceae. This is the most common species of the genus Aeromonas, which can live in both aerobic and anaerobic conditions. This strain is predominately found in treatment ponds [41,42] or domestic wastewater [43].

(v) Enterobacter mori and Enterobacter cloacae are Gram-negative, arbitrary anaerobic, rod-shaped bacteria of the same branch of Proteobacteria, Gammaproteobacteria, Enterobacteriales, Enterobacteriaceae. They are capable of creating catalase but are not able to make oxidase [44]. They were reported to be good at removing heavy metals from wastewater [45].

(vi) Pseudomonas turukhanskensis are Gram-negative bacteria of Proteobacteria, Gamaproteobacteria, Pseudomonadales, Pseudomonadaceaes. They are able to create oxidase and catalase. This strain often occurs in oily wastewaters, in particular at a temperature below $35^{\circ} \mathrm{C}$ and $\mathrm{pH} 11$ [46].

Table 4. Information on identified microorganisms in major groups.

\begin{tabular}{llll}
\hline Groups & Name of Microorganism Strains & \% Identity & E-Value * \\
\hline $5.2 \mathrm{M} 2$ & Klebsiella aerogenes & $98.00 \%$ & $2 \mathrm{e}-92$ \\
$5.2 \mathrm{M} 4$ & Exiguobacterium indicum & $99.00 \%$ & $7 \mathrm{e}-96$ \\
$5.1 \mathrm{M} 5$ & Bacillus tropicus & $99.00 \%$ & $7 \mathrm{e}-96$ \\
$4 \mathrm{C} 4$ & Aeromonas hydrophila & $100 \%$ & $3 \mathrm{e}-99$ \\
$5.1 \mathrm{M} 1$ & Enterobacter mori & $98.97 \%$ & $7 \mathrm{e}-96$ \\
$5.3 \mathrm{C} 1$ & Enterobacter cloacae & $100 \%$ & $3 \mathrm{e}-99$ \\
$4 \mathrm{C} 1$ & Pseudomonas turukhanskensis & $99.48 \%$ & $2 \mathrm{e}-97$ \\
\hline Note: ${ }^{*}$ E-value means expected value. The closer it is to zero, the better accuracy it gets.
\end{tabular}

Normally there are many microbial strains developed within a bioreactor, they depend on the types of wastewater input, temperature, $\mathrm{pH}$, and other testing conditions. Azizi et al. [43] found approximately 22 different bacterial strains from various zones of their MBBR system (using polypropylene carriers) for domestic wastewater treatment. Among them, there were five dominant microorganisms (Acinetobacter haemolyticus, Acinetobacter johnsonii, Acinetobacter lwoffii, Aeromonas sobria, and Moraxella lacunata) in the degradation of organic pollutants. Surprisingly, the DNA sequencing in the current study did not identify MBBR nitrifying species, such as Nitrosomonas, Nitrosospira, and Nitrospirae [47]. This is presumably because in the current study both organics removal and nitrification were occurring in the same reactor, and because the medium for culturing bacteria prior to DNA sequencing may have not been suitable for the growth of nitrifying bacteria.

\section{Conclusions}

This pilot-scale IFAS study using pristine and modified loofah sponges as bio-carriers provided effective treatment of municipal wastewater, both in terms of organics removal and nitrogen removal. The pilot-plant effluent consistently removed about $90 \%$ of the ammonia, meeting Vietnamese effluent 
standards. The study demonstrated that loofah sponges can be effective bio-carriers, as the loofah sponge system performed at nearly the same level as IFAS systems with plastic bio-carriers reported in the literature. Thus, loofah sponges represent an eco-friendlier alternative.

The main limitation of loofah sponge bio-carriers is their durability, which results in a very limited lifetime of sponges in water. The modification of loofah sponges with $\mathrm{CaCO}_{3}$ and polymer coating enhanced their durability to approximately one month, thus the sponges need to be replaced more frequently than every 30 days. For these modified sponges, the most practical approach to ensure consistent long-term performance would be to replace $1 / 4$ of the sponges every week. Longer-term testing and further research on alternative coating schemes are recommended.

The investigation of the microorganism community demonstrated that the loofah fibers acted well as bio-carriers/housing, with much higher microorganism density than in the wastewater within the IFAS bioreactor. The number of microorganisms in the modified loofah sponges was 20-40 times higher than that in suspension within the bioreactor.

Conventional IFAS systems (with plastic carriers) are considered more sustainable than conventional activated sludge systems because they produce a lot less waste sludge. The current study presents an even more sustainable IFAS system as its bio-carriers were prepared using a renewable resource, loofah sponges.

Author Contributions: K.M.N.; T.T.P.; Methodology: H.T.T.D., C.V.D.; Formal analysis and investigation: N.T.H.T.; Writing-original draft preparation: H.T.T.D.; Figure editing: C.V.D., Writing-review and editing: K.M.N, T.T.P., C.V.D., R.M.N.; Funding acquisition: K.M.N., T.T.P.; Supervision: R.M.N. All authors have read and agreed to the published version of the manuscript.

Funding: The research was funded by National University of Civil Engineering (NUCE), Vietnam (Research project No 13-2019/KHXD-TD) and the APC was funded partly by NUCE.

Acknowledgments: The authors would like to express high acknowledgement to National University of Civil Engineering (NUCE), Vietnam, for its financial support (Research project No 13-2019/KHXD-TD). We also would like to thank Nguyen Thuy Lien, Faculty of Environmental Engineering, National University of Civil Engineering, for helping in sample analyses. In particular, we kindly thank Hanoi Sewerage and Drainage Limited Company for hosting our pilot at Kim Lien wastewater treatment plant.

Conflicts of Interest: The authors declare no conflict of interest.

\section{References}

1. Borkar, R.; Gulhane, M.; Kotangale, A. Moving bed biofilm reactor-a new perspective in wastewater treatment. IOSR J. Environ. Sci. Toxicol. Food Technol. 2013, 6, 15-21.

2. McQuarrie, J.P.; Boltz, J.P. Moving Bed Biofilm Reactor Technology: Process Applications, Design, and Performance. Water Environ. Res. 2011, 83, 560-575. [CrossRef] [PubMed]

3. Ødegaard, H.; Rusten, B.; Westrum, T. A new moving bed biofilm reactor-applications and results. Water Sci. Technol. 1994, 29, 157. [CrossRef]

4. Rusten, B.; McCoy, M.; Proctor, R.; Siljudalen, J.G. The innovative moving bed biofilm reactor/solids contact reaeration process for secondary treatment of municipal wastewater. Water Environ. Res. 1998, 70, 1083-1089. [CrossRef]

5. Hoseinzadeh, E.; Rezaee, A.; Hossini, H. Biological Nitrogen Removal in Moving Bed Biofilm Reactor Using Ibuprofen as Carbon Source. Water Air Soil Pollut. 2016, 227, 46. [CrossRef]

6. Bassin, J.P.; Dezotti, M.; Sant'Anna, G.L., Jr. Nitrification of industrial and domestic saline wastewaters in moving bed biofilm reactor and sequencing batch reactor. J. Hazard. Mater 2011, 185, 242-248. [CrossRef] [PubMed]

7. Metcalf, E.; Abu-Orf, M.; Bowden, G.; Burton, F.L.; Pfrang, W.; Stensel, H.D.; Tchobanoglous, G.; Tsuchihashi, R. Wastewater Engineering: Treatment and Resource Recovery; McGraw Hill Education: New York, NY, USA, 2014.

8. Chu, L.; Wang, J. Comparison of polyurethane foam and biodegradable polymer as carriers in moving bed biofilm reactor for treating wastewater with a low $\mathrm{C} / \mathrm{N}$ ratio. Chemosphere 2011, 83, 63-68. [CrossRef] [PubMed]

9. Droste, R.L.; Gehr, R.L. Theory and Practice of Water and Wastewater Treatment; John Wiley and Sons: Hoboken, NJ, USA, 2018. 
10. Liu, J.; Zhou, J.; Xu, N.; He, A.; Xin, F.; Ma, J.; Fang, Y.; Zhang, W.; Liu, S.; Jiang, M. Performance evaluation of a lab-scale moving bed biofilm reactor (MBBR) using polyethylene as support material in the treatment of wastewater contaminated with terephthalic acid. Chemosphere 2019, 227, 117-123. [CrossRef] [PubMed]

11. Zhang, X.; Chen, X.; Zhang, C.; Wen, H.; Guo, W.; Ngo, H.H. Effect of filling fraction on the performance of sponge-based moving bed biofilm reactor. Bioresour. Technol. 2016, 219, 762-767. [CrossRef] [PubMed]

12. Accinelli, C.; Saccà, M.L.; Mencarelli, M.; Vicari, A. Application of bioplastic moving bed biofilm carriers for the removal of synthetic pollutants from wastewater. Bioresour. Technol. 2012, 120, 180-186. [CrossRef] [PubMed]

13. Borges, M.E.; Sierra, M.; Cuevas, E.; García, R.D.; Esparza, P. Photocatalysis with solar energy: Sunlight-responsive photocatalyst based on $\mathrm{TiO} 2$ loaded on a natural material for wastewater treatment. Sol. Energy 2016, 135, 527-535. [CrossRef]

14. Wang, S.; Peng, Y. Natural zeolites as effective adsorbents in water and wastewater treatment. Chem. Eng. J. 2010, 156, 11-24. [CrossRef]

15. Cruz-Morató, C.; Lucas, D.; Llorca, M.; Rodriguez-Mozaz, S.; Gorga, M.; Petrovic, M.; Barceló, D.; Vicent, T.; Sarrà, M.; Marco-Urrea, E. Hospital wastewater treatment by fungal bioreactor: Removal efficiency for pharmaceuticals and endocrine disruptor compounds. Sci. Total Environ. 2014, 493, 365-376. [CrossRef] [PubMed]

16. Zhao, Y.; Cao, D.; Liu, L.; Jin, W. Municipal Wastewater Treatment by Moving-Bed-Biofilm Reactor with Diatomaceous Earth as Carriers. Water Environ. Res. 2006, 78, 392-396. [CrossRef] [PubMed]

17. Bhuptawat, H.; Folkard, G.; Chaudhari, S. Innovative physico-chemical treatment of wastewater incorporating Moringa oleifera seed coagulant. J. Hazard. Mater. 2007, 142, 477-482. [CrossRef] [PubMed]

18. Laidani, Y.; Hanini, S.; Henini, G. Use of fiber Luffa cylindrica for waters traitement charged in copper. Study of the possibility of its regeneration by desorption chemical. Energy Procedia 2011, 6, 381-388. [CrossRef]

19. Henini, G.; Laidani, Y.; Souahi, F.; Hanini, S. Study of static adsorption system phenol/Luffa cylindrica fiber for industrial treatment of wastewater. Energy Procedia 2012, 18, 395-403. [CrossRef]

20. Li, S.; Liu, F.; Su, Y.; Shao, N.; Yu, D.; Liu, Y.; Liu, W.; Zhang, Z. Luffa sponge-derived hierarchical meso/macroporous boron nitride fibers as superior sorbents for heavy metal sequestration. J. Hazard. Mater. 2019, 378, 120669. [CrossRef]

21. Altınışık, A.; Gür, E.; Seki, Y. A natural sorbent, Luffa cylindrica for the removal of a model basic dye. J. Hazard Mater 2010, 179, 658-664. [CrossRef] [PubMed]

22. Iqbal, M.; Edyvean, R. Alginate coated loofa sponge discs for the removal of cadmium from aqueous solutions. Biotechnol. Lett. 2004, 26, 165-169. [CrossRef]

23. Liu, Z.; Pan, Y.; Shi, K.; Wang, W.; Peng, C.; Li, W.; Sha, D.; Wang, Z.; Ji, X. Preparation of hydrophilic luffa sponges and their water absorption performance. Carbohydr. Polym. 2016, 147, 178-187. [CrossRef] [PubMed]

24. Hideno, A.; Ogbonna, J.C.; Aoyagi, H.; Tanaka, H. Acetylation of loofa (Luffa cylindrica) sponge as immobilization carrier for bioprocesses involving cellulase. J. Biosci. Bioeng. 2007, 103, 311-317. [CrossRef] [PubMed]

25. Do, T.T.; Tran, L.V.; Bui, T.K.V.; Nguyen, T.Q. Research on the Application of Natural Materials as Biological Carriers in Wastewater Treatment for Beer Industry Using MBBR Technology; Scientific Research Report; Thuy Loi University: Hanoi, Vietnam, 2016. (In Vietnamese)

26. Panneerdhass, R.; Gnanavelbabu, A.; Rajkumar, K. Mechanical properties of luffa fiber and ground nut reinforced epoxy polymer hybrid composites. Procedia Eng. 2014, 97, 2042-2051. [CrossRef]

27. Rice, E.W.; Baird, R.B.; Eaton, A.D.; Clesceri, L.S. Standard Methods for the Examination of Water and Wastewater; American Public Health Association: Washington, DC, USA, 2012.

28. Muyzer, G.; De Waal, E.C.; Uitterlinden, A.G. Profiling of complex microbial populations by denaturing gradient gel electrophoresis analysis of polymerase chain reaction-amplified genes coding for 16S rRNA. Appl. Environ. Microbiol. 1993, 59, 695-700. [CrossRef] [PubMed]

29. Schwieger, F; Tebbe, C.C. A new approach to utilize PCR-single-strand-conformation polymorphism for $16 \mathrm{~S}$ rRNA gene-based microbial community analysis. Appl. Environ. Microbiol. 1998, 64, 4870-4876. [CrossRef] [PubMed]

30. Yuan, Q.; Wang, H.; Hang, Q.; Deng, Y.; Liu, K.; Li, C.; Zheng, S. Comparison of the MBBR denitrification carriers for advanced nitrogen removal of wastewater treatment plant effluent. Environ. Sci. Pollut. Res. 2015, 22, 13970-13979. [CrossRef] [PubMed] 
31. The Ministry of Natural Resources and Environment. QVCN40:2011/BTNMT: National Technical Regulation on Industrial Wastewater (In Vietnamese); MONRE: Cầu Giấy, Vietnam, 2011.

32. Martín-Pascual, J.; López-López, C.; Cerdá, A.; Gonzaález-Loópez, J.; Hontoria, E.; Poyatos, J.M. Comparative Kinetic Study of Carrier Type in a Moving Bed System Applied to Organic Matter Removal in Urban Wastewater Treatment. Water Air Soil Pollut. 2012, 223, 1699-1712. [CrossRef]

33. Barwal, A.; Chaudhary, R. To study the performance of biocarriers in moving bed biofilm reactor (MBBR) technology and kinetics of biofilm for retrofitting the existing aerobic treatment systems: A review. Rev. Environ. Sci. Bio. 2014, 13, 285-299. [CrossRef]

34. Im, J.-H.; Woo, H.-J.; Choi, M.-W.; Han, K.-B.; Kim, C.-W. Simultaneous organic and nitrogen removal from municipal landfill leachate using an anaerobic-aerobic system. Water Res. 2001, 35, 2403-2410. [CrossRef]

35. Sánchez, E.; Borja, R.; Travieso, L.; Martín, A.; Colmenarejo, M.F. Effect of organic loading rate on the stability, operational parameters and performance of a secondary upflow anaerobic sludge bed reactor treating piggery waste. Bioresour. Technol. 2005, 96, 335-344. [CrossRef]

36. Yoshino, Y.; Nakazawa, S.; Otani, S.; Sekizuka, E.; Ota, Y. Nosocomial bacteremia due to Kluyvera cryocrescens: Case report and literature review. IDCases 2016, 4, 24-26. [CrossRef] [PubMed]

37. Iyer, R.; Iken, B.; Damania, A. Whole genome of Klebsiella aerogenes PX01 isolated from San Jacinto River sediment west of Baytown, Texas reveals the presence of multiple antibiotic resistance determinants and mobile genetic elements. Genom. Data 2017, 14, 7-9. [CrossRef] [PubMed]

38. Vishnivetskaya, T.A.; Kathariou, S.; Tiedje, J.M. The Exiguobacterium genus: Biodiversity and biogeography. Extremophiles 2009, 13, 541-555. [CrossRef] [PubMed]

39. Kulshreshtha, N.M.; Kumar, A.; Dhall, P.; Gupta, S.; Bisht, G.; Pasha, S.; Kumar, R. Neutralization of alkaline industrial wastewaters using Exiguobacterium sp. Int. Biodeter. Biodegr. 2010, 64, 191-196. [CrossRef]

40. Taguchi, M.S.; Hanai, Y. New Wastewater treatment solution using Bacillus. Fuji Electr. Rev. 2017, 63, 54-59.

41. Dastager, S.G.; Mawlankar, R.; Sonalkar, V.V.; Thorat, M.N.; Mual, P.; Verma, A.; Krishnamurthi, S.; Tang, S.-K.; Li, W.-J. Exiguobacterium enclense sp. nov., isolated from sediment. Int. J. Syst. Evol. Micr. 2015, 65, 1611-1616. [CrossRef] [PubMed]

42. Poffe, R.; de Beeck, E.O. Enumeration of Aeromonas hydrophila from domestic wastewater treatment plants and surface waters. J. Appl. Bacteriol. 1991, 71, 366-370. [CrossRef] [PubMed]

43. Azizi, S.; Valipour, A.; Sithebe, T. Evaluation of different wastewater treatment processes and development of a modified attached growth bioreactor as a decentralized approach for small communities. Sci. World J. 2013, 2013, 156870. [CrossRef] [PubMed]

44. Grimont, F.; Grimont, P.A. The genus enterobacter. In The Prokaryotes; Dworkin, M., Falkow, S., Eds.; Springer: New York, NY, USA, 2006; Volume 6, pp. 197-214.

45. Abbas, S.Z.; Rafatullah, M.; Ismail, N.; Lalung, J. Isolation, identification, characterization, and evaluation of cadmium removal capacity of Enterobacter species. J. Basic Microbiol. 2014, 54, 1279-1287. [CrossRef] [PubMed]

46. Varghese, R. Bioaccumulation of cadmium by Pseudomonas sp. isolated from metal polluted industrial region. Environ. Res. Eng. Manag. J. 2012, 61, 58-64. [CrossRef]

47. Hoang, V.; Delatolla, R.; Abujamel, T.; Mottawea, W.; Gadbois, A.; Laflamme, E.; Stintzi, A. Nitrifying moving bed biofilm reactor (MBBR) biofilm and biomass response to long term exposure to 1 C. Water Res. 2014, 49, 215-224. [CrossRef] [PubMed]

(C) 2020 by the authors. Licensee MDPI, Basel, Switzerland. This article is an open access article distributed under the terms and conditions of the Creative Commons Attribution (CC BY) license (http://creativecommons.org/licenses/by/4.0/). 